Complex interrelations between academic competences and students' approaches to learning - mixed-methods study

\title{
Tuononen, Tarja
}

2020

Tuononen , T , Parpala , A \& Lindblom-Ylänne , S 2020 , ' Complex interrelations between academic competences and students' approaches to learning - mixed-methods study ', Journal of Further and Higher Education , vol. 44 , no. 8 , pp. 1080-1097 . https://doi.org/10.1080/0309877X.2019.16

http://hdl.handle.net/10138/326220

https://doi.org/10.1080/0309877X.2019.1648776

acceptedVersion

Downloaded from Helda, University of Helsinki institutional repository.

This is an electronic reprint of the original article.

This reprint may differ from the original in pagination and typographic detail.

Please cite the original version. 
Journal of Further and Higher Education

Complex interrelations between academic competences and students' approaches to learning - Mixed-methods study

Tarja Tuononen* Anna Parpala and Sari Lindblom-Ylänne

Centre for University Teaching and Learning (HYPE)

Faculty of Educational Sciences

University of Helsinki

Siltavuorenpenger $1 \mathrm{~A}$

P.O. Box 9, 00014 Helsinki, Finland

* Corresponding author: tarja.tuononen@ helsinki.fi, Tel. +358503175464

Tarja Tuononen ORCID: 0000-0001-9168-4185

Anna Parpala ORCID: 0000-0001-5822-6983

Sari Lindblom-Ylänne ORCID: 0000-0001-7297-7433 


\begin{abstract}
Students are expected to develop academic competences during their studies. However, research regarding the relation between academic competences and student learning is scarce. The present mixed-methods study aims to investigate the complex interrelations between academic competences and approaches to learning using both quantitative and qualitative methods. The data included 1023 graduates' survey answers and 83 interviews. The results showed that academic competences correlated positively with a deep approach to learning as well as with organised studying, and negatively with a surface approach. The qualitative analysis, however, revealed that descriptions of a deep approach were also found among graduates who evaluated academic competences less highly. Further, the results showed that putting effort into studying and seeing various competences as transferable were also positively related to academic competences and greater satisfaction with the degree obtained. The present study also showed that approaches to learning are closely intertwined with academic competences. The study suggests that the development of academic competences and an ability to identify them can be supported by emphasising deep-level learning and organised studying.
\end{abstract}

Keywords: Academic competences; approaches to learning; graduates; higher education; mixed-methods study 


\section{Introduction}

University education aims to produce academic experts for different fields of society by developing students' academic competences, such as analytical, communication, teamwork and problem-solving skills (e.g. Van Dierendonck and Van der Gaast 2013). These kinds of academic competences are seen as important learning outcomes needed in working life, but they are also needed while studying (Diseth 2007; Kreber 2003; Lizzio, Wilson and Simons 2002). Their role in studies is suggested to be crucial because they seem to increase the depth of learning and the reflectivity of the learner (Hager, Holland, and Beckett 2002). Moreover, their important position in learning processes has been found in another study which showed that a lack of academic competences has been associated with difficulties in studies (Paul et al. 2009). On the basis of these previous studies, one can assume that student learning processes can be seen as intertwined with academic competences. However, the interrelation between academic competences and approaches to learning is rather unclear. The present mixedmethods study aims to clarify the complex interrelation between academic competences and approaches to learning by exploring this interrelation using both quantitative and qualitative methods.

\section{Academic competences}

Several terms are used to indicate these kinds of competences and skills, such as key skills, generic competences, generic skills and graduates' attributes (Barrie 2006; Havard, Hughes, and Clarke 1998; Lizzio, Wilson, and Simons 2002; Strijbos, Engels, and Struyven 2015). In the present study, we use the concept of academic competence to refer to generic competences which are developed and used in an academic context and are important in academic work (e.g. Harvard, Hughes, and Clarke 1998; Mah and Ifenthaler 2017; Van Dierendonck and Van der Gaast 2013). DiPerna and Elliot (1999) have defined academic competence as a 
multidimensional construct of attitudes, behaviours, self-conceptions and skills, comprising academic skills, study skills and interpersonal skills, also known as generic skills (Dunne, Bennett, and Carré 2000; Wilson, Lizzio, and Ramsden 1997). Academic competence can be defined as including knowledge, skills and attitudes (Baartman et al. 2007; Lizzio and Wilson 2004). Furthermore, Delamare Le Deist and Winterton (2005) define competences to include conceptual competences (cognitive competence and meta-competence) as well as operational competences (functional and social competence). One previous study (Tuononen, Parpala, and Lindblom-Ylänne 2017) showed graduates' academic competences to consist of a rich variety of competences and skills - including metacognitive skills and an ability to transfer skills to another context - and that the competences were further related to high self-efficacy beliefs. In the present study, we use this wider view of academic competences, which is also in line with research by Delamare Le Deist and Winterton (2005).

The development of academic competences during university studies has been an interest of many researchers. The focus has been mainly on students' perceptions of how their studies have supported the development of their competences. University students have assessed that studying at university develops various academic competences. For example, students have reported that a university education has helped them to develop their critical thinking (Badcock, Pattison, and Harris 2010; Crebert et al. 2004; Kreber 2003; Keneley and Jackling 2011), problem-solving skills (Crebert et al. 2004; Keneley and Jackling 2011; Kember and Leung 2005), oral and written communication skills (Crebert et al. 2004; Kreber 2003; Keneley and Jackling 2011) as well as teamwork skills and interpersonal understanding (Andrew and Higson 2008; Crebert et al. 2004; Kreber 2003; Keneley and Jackling 2011). However, contradictory evidence shows that communication and collaboration skills were perceived as the least developed in many studies (Kember and Leung 2005; Keneley and Jackling 2011). In addition, Andrew and Higson (2008) found that students mentioned that their 
written communication skills had developed, but not their oral presentation skills. In addition, several studies show that university studies develop more theoretical knowledge than different competences (Monteiro, Almeida, and García-Aracil 2016; Tynjälä et al. 2006). In addition, a longitudinal study showed that not all students are able to improve their critical thinking skills during their studies (Arum and Roksa 2011).

\section{Students' approaches to learning}

Students' approaches to learning have been widely examined in higher education contexts (e.g. Diseth 2007; Herrmann, Bager-Elsborg, and McCune 2017; Hyytinen, Postareff, and Toom 2018; Lawless and Richardson 2002; Lindblom-Ylänne, Parpala, and Postareff 2018; Parpala et al. 2010). Approaches to learning describe students' intentions and study processes (Entwistle 2009; Entwistle and Peterson 2004; Entwistle and Ramsden 1983; Marton and Säljö 1997). Three approaches to learning have been identified: the deep approach, the surface approach and organised studying. Students applying a deep approach aim to understand and concentrate on analysing and relating ideas to previous knowledge as well as using evidence; in other words, they use a deep study process (Entwistle and Ramsden 1983; Entwistle and Peterson 2004). Students applying a surface approach concentrate on reproducing and memorising information, resulting in fragmented knowledge (Entwistle 2009; Entwistle and Ramsden 1983). Recently, the term 'unreflective approach' has been suggested to more deeply describe the surface approach in the $21^{\text {st }}$ century, taking into account an unreflective study process and the inability to form a coherent whole of the subject matter (Lindblom-Ylänne, Parpala, and Postareff 2018). The third approach, organised studying, refers to how systematic students are, and it includes good time-management skills, self-regulation and effort in studying (Entwistle and McCune 2004) as well as a sense of responsibility regarding studying (Entwistle 
and Peterson 2004). In general, organised studying relates more to studying than describing the student learning process (Entwistle 2009).

Evidence shows that university students tend to score the highest on the deep approach and the lowest on the surface approach (Herrmann, Bager-Elsborg, and McCune 2017; Hyytinen, Toom, and Postareff 2018). A minority of university students apply a pure surface approach (Lindblom-Ylänne, Parpala, and Postareff 2018; Parpala, Lindblom-Ylänne, Komulainen, Litmanen, and Hirsto 2010).

\section{The interrelation between academic competences and approaches to learning}

The relation between academic competences and approaches to learning usually interprets academic competences as learning outcomes and approaches to learning as indicating study process (Diseth 2007; Kreber 2003). This follows the idea of Biggs' (1987; 2003) 3P model of learning and teaching. In that model, student characteristics and the teaching context are presage factors, students' approaches to learning are process factors, and competences are seen as product factors. Studies exploring the relationship between approaches to learning and academic competences have found that the deep approach to learning and organised studying were positively and the surface approach negatively related to academic competences (Diseth 2007; Kreber 2003; Lawless and Richardson 2002; Liu, Ye and Yeung 2015; Lizzio, Wilson, and Simons 2002; Richardson and Price 2003; Sharp et al. 2017). However, for example, Hyytinen, Toom and Postareff (2018) found no relation between approaches to learning and critical thinking skills.

Interestingly, Biggs's $(1987 ; 2003) 3 \mathrm{P}$ model does not take into account the evidence that competences can also be considered part of learning processes, but only treats them as learning outcomes. Approaches to learning can include elements of different competences, making their relations even more complex. For example, the deep approach to 
learning includes elements, such as relating ideas and using evidence (Entwistle and Peterson 2004), which are closely related to competences, such as the ability to apply knowledge and critical thinking skills. In addition, organised studying requires good time-management skills (Entwistle and McCune 2004), which is also one important academic competence. Moreover, Kreber (2003) in her study took another perspective and treated competences as predictors for approaches to learning. The study showed that academic competences were the main predictors for students' deep approach to learning (explaining 14\% of the total variance) and organised studying ( $12 \%$ of the total variance). Regarding the surface approach, academic competences predicted $7.5 \%$ of the total variance, and the relation between competences and the surface approach was negative. Therefore, academic competences and approaches to learning are intertwined, as competences are embedded in approaches to learning and, on the other hand, a deep approach to learning can promote the development of academic competences. For example, evidence shows that a deep approach to learning is needed in order to develop critical thinking skills (Nelson Laird et al. 2014).

\section{The aims of the study}

The present mixed-methods study aims to clarify the complex interrelations between academic competences and students' approaches to learning. Kreber (2003) explored how academic competences, among other factors, explained the variation in deep, surface and organised studying. In the present study, we aim to explore this relation in the opposite direction. More precisely, we will examine how approaches to learning explain the variation in different academic competences following the 3 P model by Biggs $(1987 ; 2003)$. Furthermore, most studies in this area have been quantitative, with only a few studies exploring competences using a qualitative approach (Chan 2010; Kember 2009; Andrews and Higson 2008). However, we found the variation in our previous qualitative study in how Master's graduates were able to 
describe their academic competences (Tuononen, Parpala, and Lindblom-Ylänne 2017). Most graduates were able to extensively describe their competences, including those that are more demanding such as critical thinking and applying knowledge, as well as more practical competences. However, some graduates described their academic competences quite narrowly, emphasising only practical competences such as communications skills and information technology skills. Moreover, others had difficulties in describing and evaluating their competences at all (Tuononen, Parpala, and Lindblom-Ylänne 2017). The study also showed the variation in graduates' reflection skills and thus in their deep approach to learning. Thus, our previous study indicated that qualitative research is also needed in order to broaden the understanding of students' academic competences and to better understand the complex relation to students' learning. In addition, the aim of the present study is to investigate the relation between graduates' evaluations of academic competences and approaches to learning measured at the degree programme level, not the course level.

The research questions are as follows:

1. What does the survey data tell us about the relation between academic competences and approaches to learning?

1. Hypothesis: A deep approach to learning is positively and a surface approach negatively related to academic competences (Kreber 2003; Liu, Ye and Yeung 2015; Lizzio, Wilson, and Simons 2002).

2. Hypothesis: Academic competences and approaches to learning are intertwined and have a bidirectional relation (Kreber 2003; Entwistle and Peterson 2004).

2. How does the interview data deepen our understanding of the relationship between academic competences and approaches to learning? 


\section{Methodology}

\section{Participants}

This study was conducted at a research-intensive university in Finland. A total of 1023 graduates completed an electronic questionnaire at the time of their graduation. The participants were graduates who had either completed Bachelor's degrees (43\%) or Master's degrees (57\%). Most participants were from the Faculty of Arts $(n=598 ; 59 \%)$, the Faculty of Behavioural Sciences $(n=115 ; 11 \%)$ and the Faculty of Social Sciences $(n=59 ; 6 \%)$. Of the participants, $77 \%(\mathrm{n}=786)$ were female and $23 \%(\mathrm{n}=232)$ male. The percentage of female students at the university was $65 \%$. Thus, female students were overrepresented in the data. The ages varied from 21 to 69 years $(M=30, S D=7.3)$ : more than a third of the participants were younger than 26 years, half were $26-32$ years of age, and only $16 \%$ were more than 32 years of age.

Of the 1023 graduates, a total of 83 were interviewed. Of them, 59 were Master's graduates and 24 Bachelor's graduates. Most of the interviewed graduates represented the humanities, social sciences and behavioural sciences. The majority of participants were female $(72 \%, \mathrm{n}=59)$, and their ages varied from 23 to 59 years $(M=30): 17 \%$ were less than 26 years, more than half were $26-31$ years of age (59\%), and $24 \%$ were more than 32 years of age.

\section{Context}

In 2005, Finnish universities transferred to a two-level degree system: the Bachelor's degree and the Master's degree. As in most countries following the Bologna declaration, the Bachelor's degree (180 credits) is normally completed in three years and the Master's degree (120 credits) in two. In Finland, the Bachelor's degree is an intermediate degree towards the Master's degree and there is no selection process in the transition from Bachelor's level studies to Master's level studies. Most students complete both Bachelor's and Master's degrees. In Finland, all Master's 
degrees are research based, meaning that all students write a Master's dissertation, even if they will graduate to join professional life, such as doctors, lawyers or teachers.

\section{Materials}

The survey HowULearn (prev. Learn, Parpala and Lindblom-Ylänne 2012) was used to measure graduates' evaluations of their academic competences and approaches to learning. The graduates were asked to evaluate how their university studies had developed different academic competences such as critical thinking, the application of knowledge, collaboration and communication skills, and the development of new ideas. The items measuring competences were derived partly from a review of the literature and partly from an examination of previous inventories (e.g. Tynjälä et al. 2006; Wilson, Lizzio, and Ramsden 1997). In addition, HowULearn (prev. Learn, Parpala and Lindblom-Ylänne 2012) was used to measure graduates' approaches to learning. The instrument includes a 12-item modified version of the Approaches to Learning and Studying Inventory (ALSI, Entwistle and McCune 2004), and the Learning and Teaching Questionnaire (LSQ, Entwistle, McCune, and Hounsell 2003). In addition, two items were from the Revised Learning Process Questionnaire (R-LPQ9, Kember, Biggs, and Leung 2004). In those items graduates were asked to describe how they had been studying in general. Table 1 shows the factors measuring approaches to learning. The HowULearn questionnaire and the scales of approaches of learning are widely used and have been validated in Finnish and international contexts (e.g. Herrmann, Bager-Elsborg, and Parpala 2017; Hyytinen, Toom, and Postareff 2018; Karagiannopoulou, Naka, Kamtsios, Savvidou, and Michalis 2014; Parpala and Lindblom-Ylänne 2012; Parpala et al. 2010; Ruohoniemi, Forni, Mikkonen, and Parpala 2017; Rytkönen et al. 2012; Sakurai, Parpala, Pyhältö, and Lindblom-Ylänne 2016; Tuononen, Parpala, Mattsson, and Lindblom-Ylänne 2016). A 5-point Likert scale (1=totally disagree, 5 $=$ totally agree) was used to measure both academic competences and approaches to learning. 
Table 1. Factors and example of items measuring approaches to learning

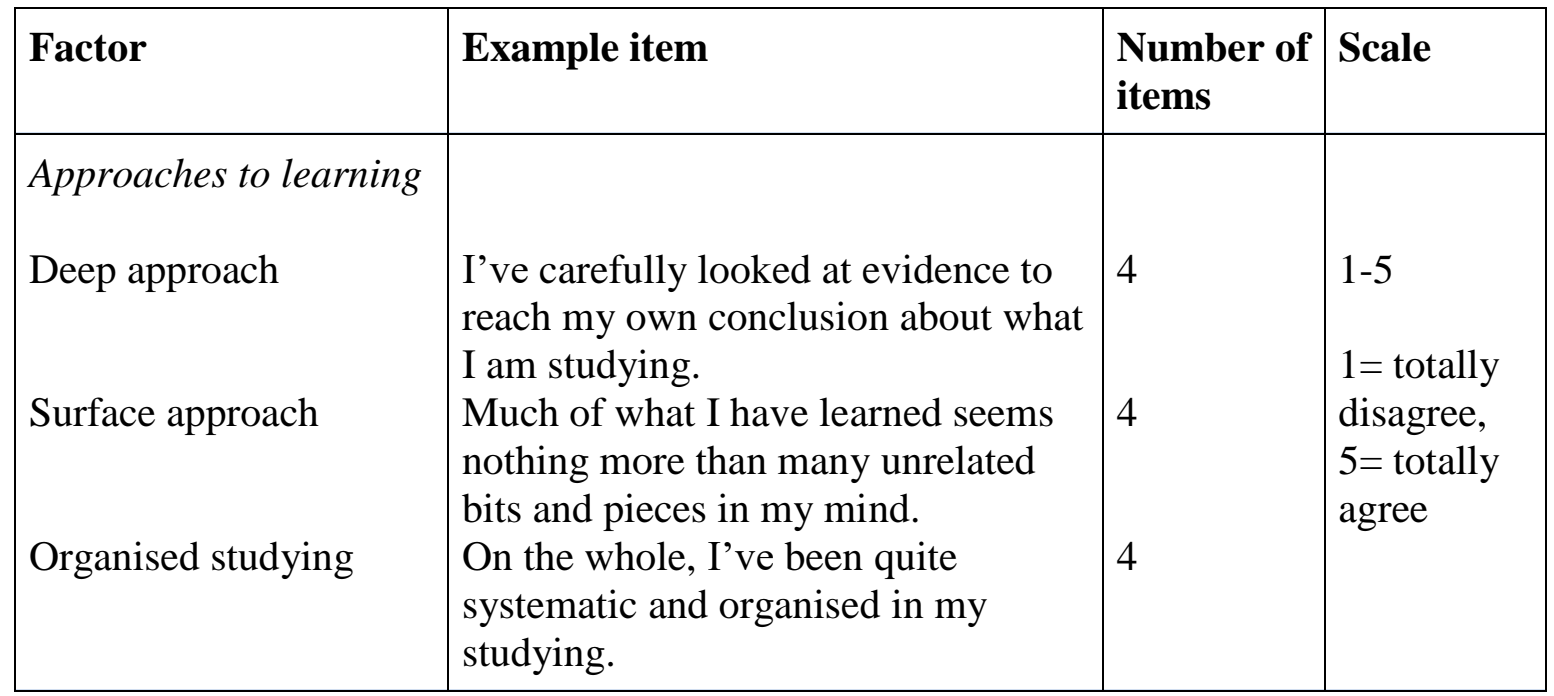

In the survey, the graduates were asked to provide their contact information if they were willing to participate in the interview. Those who volunteered were then contacted by email. The semistructured interviews focused on the graduates' evaluations of how academic competences had developed during their studies. First, the graduates freely described their academic competences, and then they were asked to describe the development of the academic competences which were asked about in the survey. The interviews also dealt more broadly with their studying and learning at the university (i.e. approaches to learning), for example, how the participants usually studied at university, why they were acquiring an academic degree and whether they have enough competences for working life. Clarifying questions were asked if the responses were unclear or too general. The interviews, conducted in Finnish by the first author, were recorded and transcribed verbatim. They lasted from 24 to 99 minutes. The extracts selected for the study were later translated into English. The participants' anonymity was ensured by giving them ID numbers, and extracts from the interviews were selected or modified in such a way that no information was revealed through which the participants could be recognised. 


\section{Analysis}

The process of analysis included two phases, quantitative and qualitative, beginning with the quantitative data. Quantitative analyses were carried out using SPSS 23, and qualitative data were analysed using content analysis (Elo and Kyngäs 2007). The analyses are presented below in more detail.

Firstly, we explored how graduates' evaluations of academic competences were related to their approaches to learning using the survey data of the 1023 graduates. Means and standard deviations of academic competences and approaches to learning were calculated at a group level. Factors of approaches to learning were constructed in our previous study showing Raykov's $\mathrm{p}$ values for the deep approach, $\mathrm{q}=0.655$, for the surface approach, $\mathrm{q}=0.652$, and for organised studying, $\mathrm{q}=0.689$ (Tuononen et al. 2016). The relations between academic competences and approaches to learning were analysed using Pearson's correlations. In addition, the interrelations between approaches to learning and academic competences were examined by linear regression analyses (forward). Separate analyses were conducted for each academic competence, using academic competences as dependent variables and approaches to learning as independent variables. The regression analyses were based on the $3 \mathrm{P}$ model definitions of approaches to learning as process factors and competences as product factors (see also Introduction; Biggs 1987; Lizzio, Wilson, and Simons 2002).

Secondly, we explored the relation between evaluations of academic competences and approaches to learning by analysing the interviews. We used the results of our previous study as a basis of the new analysis. In that study, we examined Master's graduates' evaluations of their academic competences, and as a result different profiles emerged (Tuononen, Parpala, and Lindblom-Ylänne 2017). More precisely, the results showed that graduates with wide, or rich, evaluations were able to describe and evaluate several academic competences, including demanding ones such as critical thinking, application of knowledge and perceived high-level 
cognitive benefits of their work experience, and had mostly high confidence in their success in working life. Graduates with limited evaluations described competences narrowly, emphasising only practical skills such as language and IT skills, or they had difficulties describing any academic competences. In addition, they perceived only the practical benefits of their work and had either high or low confidence in their success in working life. In the present study, our previous research was expanded on with Bachelor's graduates' interviews $(n=24)$, which were analysed searching for the same profiles. The first author analysed the interviews with a similar method as in our previous research, and the results were discussed among all authors. As a result, we found the same profiles and thus were able to combine Bachelor's and Master's graduates' data. A total of 52 of the graduates provided rich evaluations of their academic competences and 31 gave more limited evaluations, thus the whole data was derived from 83 participants. Hereafter we use the names 'Rich' evaluation group and 'Limited' evaluation group to represent the graduates with rich and limited evaluations of their academic competences. Table 2 describes the Rich and Limited evaluation groups.

Table 2. Descriptions of the Rich and Limited evaluation groups

\begin{tabular}{|l|l|}
\hline Rich evaluation group $(\mathrm{n}=52)$ & Limited evaluation group $(\mathrm{n}=31)$ \\
\hline $\begin{array}{l}\text { - Detailed analyses of demanding } \\
\text { competences such as critical thinking, } \\
\text { academic writing skills, development of } \\
\text { one's own thinking as well as practical } \\
\text { skills such as communication and }\end{array}$ & $\begin{array}{l}\text { - Only practical skills mentioned, such as } \\
\text { collaboration, language or IT skills }\end{array}$ \\
$\begin{array}{l}\text { collaboration skills were mentioned } \\
\text { - an ability to transfer high-level and } \\
\text { practical skills to another context }\end{array}$ & - Difficulty describing any competences \\
- high self-efficacy beliefs & - an ability to transfer only practical skills to \\
\hline
\end{tabular}

After profiling the graduates, we began to analyse the 83 interviews to explore how the graduates' descriptions of their academic competences and approaches to learning were related. Inductive content analysis includes phases of open coding, creating categories and abstraction 
(Elo and Kyngäs 2007). In order to capture graduates' approaches to learning, they were asked to describe their studying and learning, including their intentions and study processes. In this process, we also took into account other themes which emerged from the interviews and were related to the evaluations of academic competences. Therefore, the focus was wider than aspects of learning and study processes. The graduates' descriptions were broad, and thus we used the term 'theme' instead of 'category'. For example, the themes 'Quality of study process' and 'Satisfaction with the degree' are very different from each other but were both related to the descriptions of academic competences. The first author read through the interviews several times to find all descriptions related to the issues, and coded them. Then, similar codes were grouped under the same sub-themes. Initial themes were formed, and they were discussed with the second author. After that, the interviews were analysed in more detail in terms of subthemes. Finally, the sub-themes were discussed among all authors and were grouped under the main themes. Agreement of the themes and sub-themes between the authors was very high, almost $100 \%$. Altogether we identified three broad themes having several sub-themes. Finally, we compared sub-themes between the Rich and Limited evaluation groups to see how the descriptions of approaches to learning were related to the different evaluations of academic competences. 


\section{Results}

The relation between academic competences and approaches to learning: the quantitative analysis

Our aim was to explore the relation between graduates' evaluations of their academic competences and approaches to learning using the survey data. Firstly, the quantitative results showed that graduates scored quite highly on all academic competences (Table 3). The highest scores were for the skills of Seeing different perspectives and Critical thinking and the lowest scores were for Collaboration and communication skills and Developing new ideas. In terms of their approaches to learning, graduates scored higher on a deep approach to learning and organised studying and lower on a surface approach.

Table 3. Means and standard deviations of generic skills and approaches to learning

\begin{tabular}{l|ll}
\hline Academic competences and approaches to learning & Mean & SD \\
$\mathrm{n}=1023$ & & \\
\hline Academic competences & & \\
1. Applying knowledge & 3.71 & .96 \\
2. Collaboration and communication skills & 3.43 & 1.08 \\
3. Analysing and structuring information & 4.28 & .73 \\
4. Seeing different perspectives & 4.35 & .75 \\
5. Critical thinking & 4.35 & .76 \\
6. Making arguments and looking for solutions & 4.25 & .75 \\
7. Developing new ideas & 3.61 & .96 \\
\hline Approaches to learning & & \\
8. Deep approach & 3.81 & .68 \\
9. Surface approach & 2.21 & .76 \\
10. Organised studying & 3.56 & .76 \\
\hline
\end{tabular}

Note: Scale 1-5 
Secondly, the results showed statistically significant positive correlations between all items of academic competences and a deep approach to learning and organised studying, and statistically significant negative correlations between academic competences and a surface approach to learning (Table 4).

Table 4. The significant relationship between academic competences and approaches to learning

\begin{tabular}{|c|c|c|c|c|c|c|c|c|c|}
\hline Academic competences and & Corre & ations & & & & & & & \\
\hline 1. Applying knowledge & & & & & & & & & \\
\hline $\begin{array}{l}\text { 2. Collaboration and } \\
\text { communication skills }\end{array}$ & 0.35 & & & & & & & & \\
\hline $\begin{array}{l}\text { 3. Analysing and structuring } \\
\text { information }\end{array}$ & 0.35 & 0.30 & & & & & & & \\
\hline $\begin{array}{l}\text { 4. Seeing different } \\
\text { perspectives }\end{array}$ & 0.33 & 0.29 & 0.63 & & & & & & \\
\hline 5. Critical thinking & 0.29 & 0.24 & 0.58 & 0.72 & & & & & \\
\hline $\begin{array}{l}\text { 6. Making arguments and } \\
\text { looking for solutions }\end{array}$ & 0.30 & 0.21 & 0.56 & 0.57 & 0.59 & & & & \\
\hline 7. Developing new ideas & 0.39 & 0.33 & 0.39 & 0.42 & 0.45 & 0.51 & & & \\
\hline 8. Deep approach & 0.27 & 0.10 & 0.33 & 0.34 & 0.36 & 0.35 & 0.35 & & \\
\hline 9. Organised studying & 0.20 & 0.15 & 0.21 & 0.15 & 0.17 & 0.18 & 0.15 & 0.31 & \\
\hline 10. Surface approach & -0.28 & -0.10 & -0.24 & -0.18 & -0.15 & -0.22 & -0.23 & -0.31 & -0.22 \\
\hline
\end{tabular}

Note: All correlations are significant at the level 0.01

Next, regression analyses were conducted to explore which approach to learning had the strongest relationship with each academic competence. As seen in Table 5, a deep approach to learning was statistically significantly related to all of the academic competences, except collaboration and communication skills. Standardised regression coefficient $\beta$ showed that a 
deep approach to learning had the statistically significantly and strongest relation to all of the competences. A surface approach had a negative, statistically significant relation to all other competences, except for critical thinking, with which it was not related statistically significantly. Organised studying was positively and statistically significantly associated with Applying knowledge, Collaboration and communication skills, Analysing and structuring information, Critical thinking and Making arguments and looking for solutions. All three approaches to learning had a statistically significant relation to the competences of Applying knowledge, Analysing and structuring information and Making arguments and looking for solutions. 
Table. 5. Summary of the regression analyses on the relations between academic competences and approaches to learning

\begin{tabular}{|l|l|l|l|l|l|l|l|}
\hline & $\begin{array}{l}\text { Applying } \\
\text { knowledge } \\
\beta\end{array}$ & $\begin{array}{l}\text { Collaboration } \\
\text { and } \\
\text { communication } \\
\text { skills b } \\
\beta\end{array}$ & $\begin{array}{l}\text { Analysing and } \\
\text { structuring } \\
\text { information } \\
\beta\end{array}$ & $\begin{array}{l}\text { Seeing } \\
\text { different } \\
\text { perspectives } \\
\beta\end{array}$ & $\begin{array}{l}\text { Critical } \\
\text { thinking } \\
\beta\end{array}$ & $\begin{array}{l}\text { Making } \\
\text { arguments and } \\
\text { looking for } \\
\text { solutions } \\
\beta\end{array}$ \\
\hline Deep approach & $.17^{* *}$ & - & $\begin{array}{l}\text { Developing } \\
\text { new ideas } \\
\beta\end{array}$ \\
\hline $\begin{array}{l}\text { Surface } \\
\text { approach }\end{array}$ & $.11^{* *}$ & $-.07^{* *}$ & $.32^{* *}$ & $.34^{* *}$ & $.30^{* *}$ \\
\hline $\begin{array}{l}\text { Organised } \\
\text { studying }\end{array}$ & $.20^{*}$ & $.13^{* *}$ & $-.15^{* *}$ & $-.07^{*}$ & - & $-.11^{*}$ & $.31^{* *}$ \\
\hline
\end{tabular}

$* \mathrm{p}<.05, * * \mathrm{P}<0.001$

${ }^{\mathrm{a}} \mathrm{R}=0.348$, adjusted $\mathrm{R}^{2}=0.12, \mathrm{~F}(3,986)=45.16, \mathrm{p}=<.001$

${ }^{\mathrm{b}} \mathrm{R}=0.163$, adjusted $\mathrm{R}^{2}=0.24, \mathrm{~F}(2,987)=13.40, \mathrm{p}=<.001$

${ }^{\mathrm{c}} \mathrm{R}=0.369$, adjusted $\mathrm{R}^{2}=0.13, \mathrm{~F}(3,985)=51.67, \mathrm{p}=<.001$

${ }^{\mathrm{d}} \mathrm{R}=0.348$, adjusted $\mathrm{R}^{2}=0.12, \mathrm{~F}(2,987)=68.12, \mathrm{p}=<.001$

${ }^{\mathrm{e}} \mathrm{R}=0.367$, adjusted $\mathrm{R}^{2}=0.13, \mathrm{~F}(2,985)=76.66, \mathrm{p}=<.001$

${ }^{\mathrm{f}} \mathrm{R}=0.377$, adjusted $\mathrm{R}^{2}=0.14, \mathrm{~F}(3,984)=54.45, \mathrm{p}=<.001$

${ }^{\mathrm{g}} \mathrm{R}=0.377$, adjusted $\mathrm{R}^{2}=0.14, \mathrm{~F}(2,977)=81.14, \mathrm{p}=<.001$ 
Themes and sub-themes in relation to evaluations of academic competences: the qualitative analysis

Following the quantitative analysis, we analysed graduates' descriptions of their study processes in order to see how approaches to learning were related to academic competences. We found three broad themes which were related to evaluations of academic competences: (1) Quality of the study process, which was further divided into the study process and the reason for studying, (2) Transferability of academic competences, and (3) Satisfaction with the degree. Table 6 summarises the themes and sub-themes. 
Table 6. Themes and sub-themes related to evaluations of academic competences

\begin{tabular}{|c|c|}
\hline Themes & Sub-themes \\
\hline $\begin{array}{l}\text { 1. Quality of study process } \\
\text { 1.1 Study process } \\
\text { 1.2 Reason for studying }\end{array}$ & 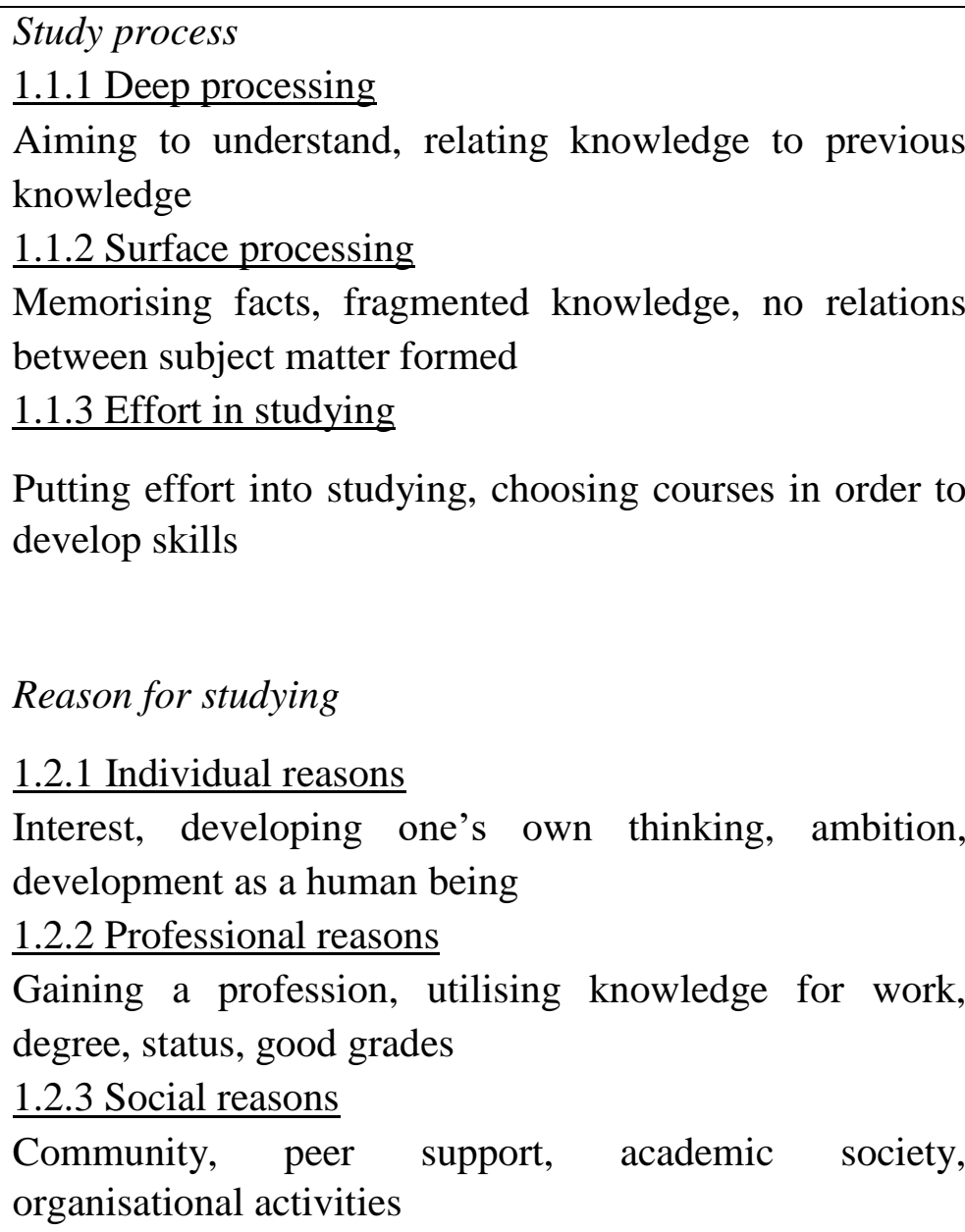 \\
\hline $\begin{array}{l}\text { 2. Transferability of } \\
\text { academic competences }\end{array}$ & $\begin{array}{l}\text { Transferable high-level skills } \\
\text { High-level cognitive skills and practical skills, can be } \\
\text { learned at university and used in working life, basis for } \\
\text { future learning } \\
\text { Transferable practical skills } \\
\text { Specific and concrete skills such as research methods or } \\
\text { software, directly usable at work }\end{array}$ \\
\hline $\begin{array}{l}\text { 3. Satisfaction with the } \\
\text { degree }\end{array}$ & $\begin{array}{l}\text { High satisfaction } \\
\text { Highly satisfied with the degree } \\
\text { Low satisfaction } \\
\text { Descriptions of dissatisfaction, less satisfied or uncertain } \\
\text { about satisfaction with the degree }\end{array}$ \\
\hline
\end{tabular}




\section{Themes related to academic competences in relation to the Rich and Limited evaluation}

groups

The basis of analysis was our previous study which showed that graduates represented either rich or limited evaluations of their academic competences (introduced in Table 2 and Tuononen, Parpala, and Lindblom-Ylänne 2017). Before a more detailed qualitative analysis, we checked the correlations between the academic competences and approaches to learning in the data representing the Rich and Limited evaluation groups. Because of the small number of the graduates in both groups $(n=83)$, the analyses were done for the whole sample. The correlations were in line with the correlations in the whole data. Next, the themes and subthemes are presented in more detail, and the Rich and Limited evaluation groups are compared.

\section{Quality of the study process}

The first theme, Quality of the study process, was divided into the 'study process' and the 'reason for studying'. The study process included three sub-themes: deep processing, surface processing and effort in studying. Descriptions of the deep processing of study material were given in both the Rich and Limited evaluation groups. These descriptions revealed that the graduates aimed to understand the subject matter and they actively processed information, for example, by relating new knowledge to previous knowledge and seeking relations between different types of subject matter. In addition, the participants' descriptions revealed that deep understanding requires different competences such as analysing and structuring information, as in the following:

I like to write essays even though it takes more time. But it is rewarding because you can remember those things afterwards since you have analysed and structured information and modified the text many times. 
The second sub-theme, surface processing, featured descriptions of rote learning. In addition, some descriptions revealed that graduates had not integrated content into a coherent whole. All of the descriptions reflecting this category were mentioned by the Limited evaluation group. A number of descriptions also revealed that some graduates had aimed to understand the subject matter but their study processes did not support their understanding. In the following extract a graduate describes his/her studying:

My studying has been cramming for the exams. ... I read the books in a week and then I went to the exam and two days later I had forgotten almost everything. But I understand that it also depends a lot on yourself.

The third sub-theme, effort in studying, consisted of descriptions of putting effort into studying and learning, especially in terms of developing academic competences. This was the most distinctive aspect of studying between the Rich and Limited evaluation groups. Graduates in the Rich group emphasised their own activity in learning competences, whereas graduates in the Limited group did not. This sub-theme also included statements that graduates had chosen courses which involved group work or presentations because they viewed these as useful for working life. There were also descriptions of graduates having written essays even when they considered them difficult and time-consuming compared to book exams, because they wanted to better understand the content and learn academic writing skills. Thus, they were also willing to take on challenges. In the following extract, a graduate describes deliberately developing academic competences:

I've chosen presentation courses and writing courses and I think that they have been very useful. I have learned writing skills and presentation skills from these courses.

Some graduates in the Limited evaluation group stated that they had chosen the easiest way to study even when they realised that it was not the best way to study. One graduate described his/her study effort as follows: 
Book exams were the easiest way to study. Writing an essay would have required a deep understanding and writing skills.

Both the Rich and Limited evaluation groups described the studies as being theoretical and that the graduates would have liked more practice in their studies. However, a qualitative difference was noted between the graduates, one which also relates to effort in studying. The Rich evaluation group most often stated that they had themselves tried to consider how theoretical knowledge could be used in practice. They understood that the studies were theoretical in nature and therefore had actively tried to search for practical applications of the theories, for example, from the work they have done during their studies.

We studied the theory but then the application depends on the students themselves. And when you actually find employment, then you have to think about these theories.

In the next extract, a graduate from the Limited evaluation group describes the application of theoretical knowledge to working life:

There is no time to think about what to do in practice with the subject matter that I've learned, so that's why I feel really frustrated that I have studied many years and I cannot concretely use it in my work after my studies.

\section{Reason for studying}

The second part of the theme of Quality of the study process was the Reason for studying. It included three sub-themes: individual, professional and social reasons. The results revealed that there were no differences between the Rich and Limited evaluation groups. Thus, in both groups there were descriptions of each sub-theme, and individual graduates sometimes mentioned several sub-themes. The first sub-theme, individual reasons, included descriptions of interest and developing one's own thinking. In addition, ambition, a passion to learn and a liking for challenges were mentioned as reasons for their studies. Individual reasons were most often mentioned in both groups. The following extract is an example of an individual reason: 
Well, feeling that you can develop yourself and that every day you are able to do something new and learn new things.

The second sub-theme, professional reasons, consisted of descriptions related to a new profession or professional growth. For example, entering a new profession or otherwise gaining employment and acquiring new skills were mentioned. Moreover, graduates in both the Rich and Limited evaluation groups mentioned that they wanted to apply the knowledge they had acquired later in working life. In addition, the descriptions revealed that the goal of some graduates was to earn a university degree, status or good grades, which are more external factors, but usually related to employment. For example, the degree could be required for a specific job. The next example illustrates a professional reason:

Applying knowledge to practice. I have made all my choices so that they would be useful for me in working life too.

The third sub-theme, social reasons, included descriptions of social aspects of studying and learning. No differences in this sub-theme were found between the Rich and Limited evaluation groups. In both groups, graduates mentioned that belonging to academia or a research community, peer support and organisational activities had been important during their studies. Some descriptions revealed that learning together and from others had been important.

A social community. My friends were also from the university because I had moved from elsewhere. We had a lot of discussions during lunches and we often talked about things to be learned and related them to our work experience.

\section{Transferability of academic competences}

The second theme, Transferability of academic competences, was related to the learning and study process and differentiated the Rich and Limited evaluation groups. Two sub-themes, transferable high-level skills and transferable practical skills, were identified. The sub-theme transferable high-level skills included descriptions of high-level cognitive skills such as engaging in critical thinking, analysing information and applying knowledge, as well as 
describing practical skills that can be learned at university and then used in working life. Descriptions of transferable high-level skills were mostly mentioned in the Rich evaluation group. In the following extract, a graduate who is now a classroom teacher describes how theories can be applied in practice, representing the sub-theme of transferable high-level skills:

Some of the students wondered why we read theory. ... I think that when you have read the theory and when a problem situation comes in the classroom, you are able to solve the problem. ... So I think that theory is something that helps you to discuss issues and look for more information.

The sub-theme transferable practical skills included the idea that generic skills are practical skills that can be used concretely at work. Graduates in the Limited evaluation group most often mentioned transferable practical skills. The following extract reveals that competences which can be used in working life should be very concrete:

Field courses...there I have done something concrete and I have learned a variety of things which will be useful in working life. But only one course at university relates to the work that $\mathrm{I}$ do at the moment.

In addition, there were descriptions which revealed that the competences needed in working life were felt to be very different from those developed during studies. The next extract represents this sub-theme well:

It [the degree] provides competence for doctoral studies, nothing else. It's not clear how mathematics can be used in practice.

\section{Satisfaction with the degree}

The third theme, Satisfaction with the degree, emerged from the data when graduates described whether they have developed enough competences for working life. Two sub-themes were discerned: high satisfaction and low satisfaction. The results showed that most of the graduates from the Rich evaluation group were satisfied with the degree. Only one graduate in this group said that he was only partly satisfied. High satisfaction was expressed in descriptions of 
graduates having gained all of the competences needed in working life, or at least the ability to learn in working life. Some also stated that theoretical understanding is important and they had the most up-to-date knowledge in their field, which is valuable at work. There were also expressions of appreciations of education and of an academic degree, and that a degree provides opportunities for working life. A graduate in the Rich evaluation group describes:

I gained enough knowledge and skills from university that I'm able to develop myself and become an expert at work.

Graduates in the Limited evaluation group usually reported that they had not developed very many competences for working life and thus were not satisfied with their degree. However, there were also graduates in this group who were satisfied with their degree because it was seen to offer opportunities to apply for academic jobs. Among the Limited evaluation group were also graduates who were uncertain about their satisfaction. In the following, graduates from the Limited evaluation group describe their satisfaction with the degree:

I'm not sure whether it [university education] has given good working skills. Because what the university teaches I feel is so abstract that to apply it to work it is difficult.

So I'm not completely satisfied with my degree, I've never been, and I'm certainly not going to be. I would need more substance knowledge.

A summary of the themes and sub-themes in relation to the Rich and Limited evaluation groups is presented in Table 7 . 
Table 7. Themes and sub-themes in relation to the Rich and Limited evaluation groups

\begin{tabular}{|l|l|l|}
\hline Themes & $\begin{array}{l}\text { Sub-themes related to Rich } \\
\text { evaluation group }(\mathrm{n}=52)\end{array}$ & $\begin{array}{l}\text { Sub-themes related to } \\
\text { Limited evaluation group } \\
(\mathrm{n}=31)\end{array}$ \\
\hline Quality of the study process & $\begin{array}{l}\text { Deep processing } \\
\text { Lack of surface processing } \\
\text { Effort in studying }\end{array}$ & $\begin{array}{l}\text { Deep processing } \\
\text { Surface processing } \\
\text { Lack of effort in studying }\end{array}$ \\
$\begin{array}{l}\text { Transferability of } \\
\text { acaademic competences }\end{array}$ & $\begin{array}{l}\text { Individual, professional and } \\
\text { social reasons } \\
\text { Satisfaction with the degree }\end{array}$ & $\begin{array}{l}\text { Individual, professional and } \\
\text { social reasons }\end{array}$ \\
& High satisfaction & $\begin{array}{l}\text { Transferable practical skills } \\
\text { Trable high-level } \text { skills }\end{array}$ \\
\hline
\end{tabular}

\section{Discussion}

The present study aimed to explore the complex interrelations between graduates' evaluations of academic competences and approaches to learning using both quantitative and qualitative methods. The results of the quantitative analysis were in line with previous survey studies showing graduates scoring highly for different competences (Arnold et al. 1999; Badcock, Pattison, and Harris 2010; Keneley and Jackling 2011; Kember and Leung 2005). Moreover, as in previous quantitative studies, we also found that the evaluations of academic competences were positively related to the deep approach to learning as well as to organised studying, and negatively related to the surface approach (Liu, Ye, and Yeung 2015; Kreber 2003; Richardson and Price 2003; Lizzio, Wilson, and Simons 2002). The present study highlighted the role of the deep approach to learning as it had stronger relations with academic competences than the surface approach and organised studying. Furthermore, the present study showed in more detail how different approaches to learning were related to different academic competences. All of 
the competences to which the deep approach strongly related, such as engaging in critical thinking, seeing different perspectives, developing new ideas and making arguments and looking for solutions, are the competences which require high cognitive abilities and determine the deep approach to learning. In addition, the interviews revealed that deep study processes require the use of competences and skills such as the ability to analyse and structure information. Therefore, these results seem to confirm our hypothesis that the relation between academic competences and approaches to learning is bidirectional, and different academic competences are intertwined with approaches to learning, especially with the deep approach to learning.

Students vary in how much they had improved their critical thinking skills during their studies (Arum and Roksa 2011). Similarly, in our previous study variation was found in how graduates were able to describe their academic competences, resulting in both rich and limited evaluations (Tuononen, Parpala, and Lindblom-Ylänne 2017). When these graduates with rich and limited evaluations described their approaches to learning (i.e. intentions and study processes) in the present study, the qualitative analysis revealed three themes related to the evaluations of academic competences: Quality of the study process, Transferability of academic competences and Satisfaction with the degree. In terms of the quality of the study process, the results showed that the Rich evaluation group more often described deep processes of studying and that all descriptions of a surface approach to learning were from graduates in the Limited evaluation group. Using mixed methods, we showed that graduates in the Limited evaluation group expressed both deep and surface approaches to learning. The fact that the deep approach to learning was found in both groups may be because most university students use the deep approach to learning more often than the surface approach (Parpala et al. 2010). The deep approach is a more favourable way of learning, and accordingly many students describe aiming at understanding, although the reality might be different. For example, Hyytinen, Toom, and 
Postareff (2018) found that students did not differ in the deep approach to learning even when their performance on a critical thinking test varied.

It seems that applying the deep approach to learning is not enough to gain an ability to reflect on one's competences because effort management and self-regulation skills are also needed. The interviews from the present study further revealed that effort in studying was the most distinguishing factor between the Rich and Limited evaluation groups, because the Limited evaluation group did not mention putting effort into studying. Thus, students' activity in learning plays a significant role in developing generic competences (Arum \& Roksa 2011; Choi and Rhee 2014). Furthermore, there is evidence that self-regulation and a lack of regulation have stronger relations to generic skills than the deep approach (Zeegers 2004). In addition, self-regulation is positively related to the deep approach and negatively to the surface approach (Heikkilä and Lonka 2006; Räisänen, Postareff, and Lindblom-Ylänne 2016). Thus, it seems that self-regulation skills, which consist of setting goals for learning, monitoring learning and studying as well as reflecting on learning afterwards, are important to develop during studies and help in developing competences (Zimmerman 2002). However, many students have difficulties in reflecting on their learning, indicating a lack of metacognitive skills (Smith, Clegg, Lawrance \& Todd 2007).

Another aspect of the Quality of the study process theme was the reason for studying, and the results showed that the Rich and Limited evaluation groups did not differ in terms of their reasons for studying. It seems that the graduates' study process, such as applying a deep approach and putting effort into studying, is a more important factor for developing academic competences than their reasons for studying. Moreover, the results of this research, as in previous studies, showed that many students did not perceive the acquisition of generic skills as a goal in itself (Gedye, Fender, and Chalkley 2004). 
The second theme, Transferability of academic competences, showed that graduates differed in the kinds of competences they saw as transferable. Graduates in the Rich evaluation group described high-level skills as being transferable, whereas the Limited evaluation group stated that only practical, specific and concrete skills can be directly applied to work. This finding echoes a previous study where students with a 'cookbook orientation' applied a surface approach to learning and emphasised certain knowledge and practical value (Lonka et al. 2008), similarly to graduates in the Limited evaluation group, who also highlighted practice in studying as well as elements of a surface approach to learning. Further, the present study revealed that graduates need more practice in their studies, a finding also from previous research (Crebert et al. 2004). However, the ability to transfer competences requires high-level learning skills and opportunities to apply knowledge (Bennett, Dunne, and Carré 1999), as well as motivation and self-regulation skills (Gegenfurtner et al. 2009; Billing 2007). Our previous study showed that graduates in the Rich evaluation group were also able to perceive high-level cognitive benefits of their work experience for their studies, whereas the Limited evaluation group saw only practical benefits (Tuononen, Parpala, and Lindblom-Ylänne 2017). Thus it seems that graduates in the Rich evaluation group were motivated to put more effort into developing their academic competences and were able to perceive how these skills could be transferred into different contexts.

The third theme, Satisfaction with the degree, emerged from the interviews and was related to graduates' evaluations of academic competences. Graduates in the Rich evaluation group were more often satisfied with their degrees and the development of competences, whereas graduates in the Limited evaluation group had more variation, ranging from satisfaction to no satisfaction. Similarly, previous studies have found that students who described having developed a larger variety of competences were also more satisfied with their university studies (Grace et al. 2012; Lizzio, Wilson, and Simons 2002). This is important 
because it has been shown that a positive educational experience is related to later satisfaction at work (Mora, García-Aracil, and Vila 2007).

The present mixed-methods study showed that graduates scored high on the academic competences measured by the surveys, but there was more variation in their ability to identify and freely describe their academic competences in the interviews. Thus the present study indicates that for some graduates it is very difficult to identify competences without any given options and that metacognitive skills are also needed in order to reflect on competences. Individual differences in the ability to evaluate competences should therefore be taken more into account. In addition, the study showed that graduates' evaluations of diverse academic competences were related to a deep approach to learning and the effort put into studying as well as the ability to see how these competences can be used in working life. Graduates with these abilities were also more likely to be satisfied with their degree. The present study showed that approaches to learning are closely intertwined with different academic competences, especially with a deep approach and organised studying (Nelson Laird et al. 2014; Kreber 2003).

Figure 1. A summary of the main significant findings of the quantitative and qualitative results

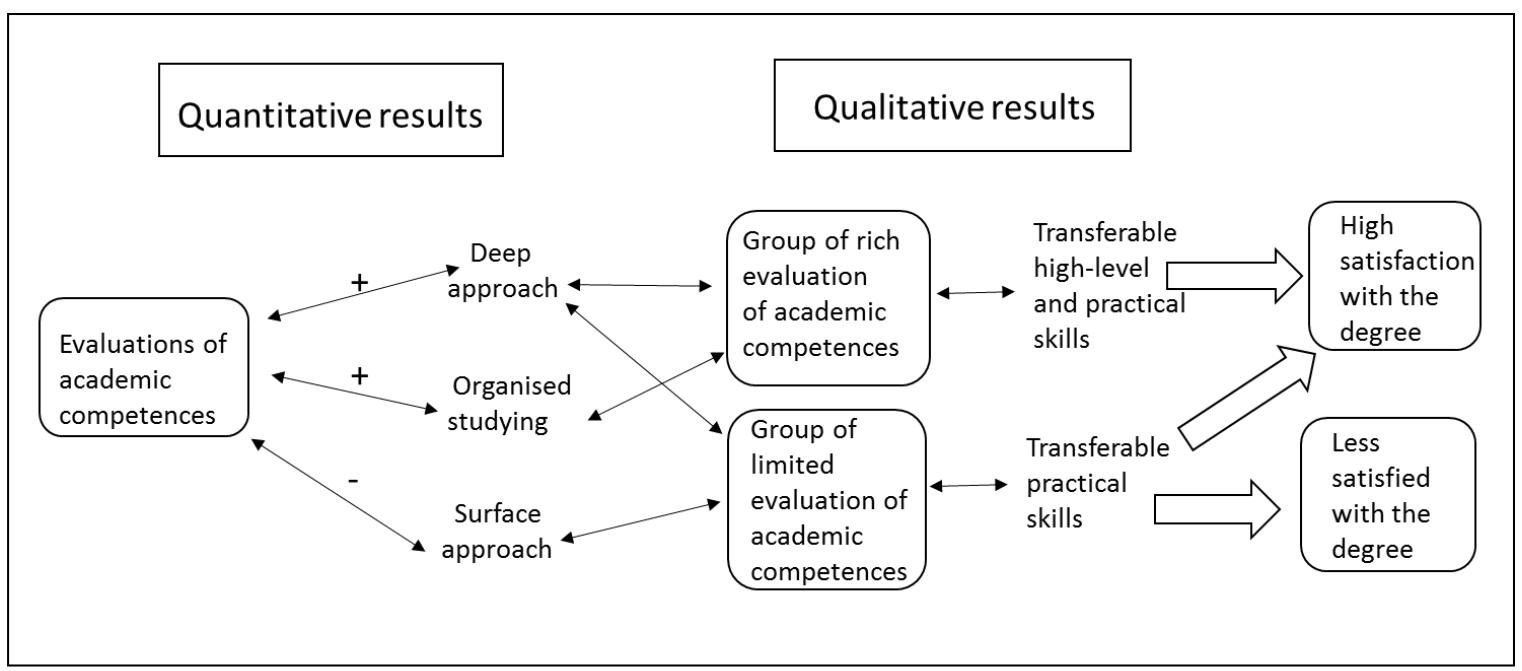


A few practical implications can be suggested for developing students' academic competences and for helping them to identify their academic competences. Firstly, it is important that students understand the importance and relevance to future work of different academic competences so that they are motivated to develop them during their studies (Crebert et al. 2004; Lizzio and Wilson 2004). Secondly, although we discussed surveys not necessarily being the best way to explore the development of academic competences, they can be used not only as research instruments but also as a self-reflection tool to recognise the academic competences that students should have learned at university. Thirdly, the present study highlights the notion that the development of competences and an ability to identify them can be supported by emphasising deep-level learning and organised studying as well as by providing activating learning environments, cooperative learning, a flipped learning environment and the use of realworld examples (Choi and Rhee 2014; Ehiyazaryan and Barraclough 2009; Vaatstra and De Vries 2007; Zainuddin and Perer 2017). In addition, the transfer of competences can be facilitated, for example, by defining specific learning objectives, encouraging students to reflect and arranging collaborative learning environments (Jackson 2016). Finally, the ability to identify academic competences and an awareness of how these competences can be used in working life are essential for graduates' employability and thus should be given more emphasis during studies.

Acknowledgements: This research was funded by Alfred Kordelin Foundation for Tarja Tuononen 


\section{References}

Andrews, J., and S. Higson. 2008. "Graduate Employability, 'Soft' Skills versus 'Hard' Business Knowledge: a European Study." Higher Education in Europe 33 (4): 411-422. doi: 10.1080/03797720802522627.

Arnold, J., J. Loan-Clarke, A. Harrington, and C. Hart. 1999. "Students' Perceptions of Competence Development in Undergraduate Business-Related Degrees." Studies in Higher Education 24 (1): 43-59. doi:10.1080/03075079912331380138.

Arum, R., and J. Roksa. 2011. "Academically Adrift. Limited Learning on College Campuses. "Chicago: The University of Chicago Press.

Baartman, L.K.J., T.J. Bastiaens, P. A. Kirschner, and C.P.M. Van der Vleuten. 2007. "Evaluating Assessment Quality in Competence-Based Education: A Qualitative Comparison of Two Frameworks." Educational Research Review 2: 114-129. doi: 10.1016/j.edurev.2007.06.001.

Badcock, P.B.T., P.E. Pattison, and K-L. Harris. 2010. Developing Generic Skills Through University Study: a Study of Arts, Science and Engineering in Australia." Higher Education 60 (4): 441-458. doi: 10.1007/s10734-010-9308-8.

Barrie, S. C. 2006. "Understanding What We Mean by the Generic Attributes of Graduates". Higher Education 51: 215-241. doi: 10.1007/s10734-004-6384.

Biggs, J. (2003). Teaching for quality learning at university. ( $2^{\text {nd }}$ ed.) Buckingham: SRHE \& Open University Press.

Biggs, J. (1987). Students approaches to learning and studying. Melbourne: Australian Council for Educational Research.

Bennett, N., E. Dunne, and C. Carré. 1999. "Patterns of Core and Generic Skill Provision of Higher Education." Higher Education 37 (1): 71-93. doi: 10.1023/A:1003451727126. 
Billing, D. 2007. "Teaching for Transfer of Core/Key Skills in Higher Education: Cognitive Skills." Higher Education 53 (4): 483-516. doi: 10.1007/s10734-005-5628-5.

Chan, W. S. C. 2010. "Students' Understanding of Generic Skills Development in a University in Hong Kong." Procedia and Social Sciences 2 (2): 4815-4819. doi: 10.1016/j.sbspro.2010.03.776.

Choi, B. K., and B. S. Rhee. 2014. "The Influences of Student Engagement, Institutional Mission, and Cooperative Learning Climate on the Generic Competency Development of Korean Undergraduate Students." Higher Education 67: 1-18. doi: 10.1007/s10734-0139637-5.

Crebert, G., M. Bates, B. Bell, C-J. Patrick, and V. Gragnolini. 2004. "Developing Generic Skills at University, During Work Placement and in Employment: Graduates' Perceptions." Higher Education Research \& Development 23 (2): 147-165. doi: $10.1080 / 0729436042000206636$.

Delamare Le Deist, F. and J. Winterton. 2005. "What is Competence?" Human Resource Development International 8 (1): 27-46.

DiPerna, J.C., and S.N. Elliott. 1999. "Development and Validation of the Academic Competence Evaluation Scales." Journal of Psychoeducational Assessment 17 (3): 207225.

Diseth, Å. 2007. "Approaches to Learning, Course Experience and Examination Grade among Undergraduate Psychology Students: Testing of Mediator Effects and Construct Validity." Studies in Higher Education 32 (3): 373-388. doi: $10.1080 / 03075070701346949$.

Dunne, E., N. Bennett, and C. Carré. 2000. "Skill Development in Higher Education and Employment." In Differing Visions a Learning Society. Research Findings, edited by F. Coffield, 105-137. Bristol: The Policy Press. 
Ehiyazaryan, E., and N. Barraclough. 2009. "Enhancing Employability: Integrating Real World Experience in the Curriculum." Education + Training 51 (4): 292-308. doi: $10.1108 / 00400910910964575$.

Elo, S., and H. Kyngäs. 2007. "The Qualitative Content Analysis Process." Journal of Advanced Nursing 62 (1): 107-115. doi: 10.1111/j.1365-2468.2007.04569-x.

Entwistle, N. 2009. "Teaching for understanding at university. Deep approaches and distinctive ways of thinking." Basingstoke: Palgrave MacMillan.

Entwistle, N.J., and V. McCune. 2004. "The Conceptual Base of Study Strategies Inventories in Higher Education." Educational Psychology Review 16 (4): 325-345. doi: 10.1007/s10648-004-0003-0.

Entwistle, N., V. McCune, and J. Hounsell. 2003. "Investigating Ways of Enhancing University Teaching-Learning Environments: Measuring Students' Approaches to Studying and Perceptions of Teaching." In Unravelling Basic Components and Dimensions of Powerful Learning Environments edited by E. De Corte, L. Verschaffel, N. Entwistle, and J. van Merrienboer, 89-108. Oxford: Elsevier Science.

Entwistle, N. J., and E. R. Peterson. 2004. "Conceptions of Learning and Knowledge in Higher Education: Relationships with Study Behaviour and Influences of Learning environments." International Journal of Educational Research 41: 407-428. doi:10.1016/j.ijer.2005.08.009.

Entwistle, N., and P. Ramsden. 1983. "Understanding Student Learning." London: Croom Helm.

Gedye, S., E. Fender, and B. Chalkley. 2004. "Students' Undergraduate Expectations and PostGraduation Experiences of the Value of a Degree." Journal of Geography in Higher Education 28 (3): 381-396. doi: 10.1080/0309826042000286956. 
Gegenfurtner, A., K. Veermans, D. Festner, and H. Gruber. 2009. "Motivation to Transfer Training: An Integrative Literature Review." Human Resource Development Review 8 (3): 403-123. doi: 10.1177/1534484309335970.

Grace, D., S. Weaven, K. Bodey, M. Ross, and K. Weaven. 2012. "Putting Student Evaluations into Perspective: The Course Experience Quality and Satisfaction Model." Studies in Educational Evaluation $38 \quad$ (2): $35-43 . \quad$ Doi: http://dx.doi.org/10.1016/j.stueduc.2012.05.001.

Hager, P., S. Holland, and D. Beckett. 2002."Enhancing the Learning and Employability of Graduates: The role of Generic Skills " Business/Higher education round table 9: 1-16.

Havard, M., M. Hughes, and J. Clarke. 1998." The Introduction and Evaluation of Key Skills in Undergraduate Courses." Journal of Further and Higher Education 22 (1): 61-68.

Herrmann, K. J. A. Bager-Elsborg, and V. McCune. 2017. Investigating the relationships between approaches to learning, learner identities and academic achievement in higher education. Higher Education 74: 385-400. doi: 10.1007/s10734-016-9999-6.

Herrmann, K. J., A. Bager-Elsborg, and A. Parpala. 2017. "Measuring Perceptions of the Learning Environment and Approaches to Learning: Validation of the Learn Questionnaire". Scandinavian Journal of Educational Research 61 (5): 526-539. doi: $10.1080 / 00313831.2016 .1172497$

Heikkilä, A, and K. Lonka. 2006. Studying in Higher Education: Students' Approaches to Learning, Self-Regulation, and Cognitive Strategies. Studies in Higher Education 31(1): 99-117. doi: 10.1080/03075070500392433.

Hyytinen, H., A. Toom, and L. Postareff. 2018. "Unraveling the Complex Relationship in Critical Thinking, Approaches to Learning and Self-Efficacy Beliefs among First-Year Educational Science Students." Learning and Individual Differences 67: 132-142. doi: 10.1016/j.lindif.2018.08.004. 
Jackson, D. 2016. "Modelling Graduate Skill Transfer from University to the Workplace." Journal of Education and Work 29 (2): 199-231. doi: 10.1080/13639080.2014.907486.

Karagiannopoulou, E., K. Naka, S. Kamtsios, E. Savvidou, and L. Michalis. 2014. "Medical Students' Approaches to Learning before and After Cardiology Problem-Based Learning Practice." Journal of Contemporary Medical Education 2(3): 152-157. doi: $10.5455 / \mathrm{jcme} .20140928040405$

Kember, D. 2009. "Nurturing Capabilities through a Teaching and Learning Environment which Provides Practice in Their Use." Higher Education 57: 37-55. doi: 10.1007/s10734-008-9131-7.

Kember, D., Biggs, J. \& Leung, D. (2004). Examining the multidimensionality of approaches to learning through the development of a revised version of the learning process questionnaire. British Journal of Educational Psychology, 74, 261-280.

Kember, D., and D. Y. P Leung. 2005. "The Influence of the Teaching and Learning Environment on the Development of Generic Capabilities Needed for a KnowledgeBased Society." Learning Environments Research 8: 245-266. doi: 10.1007/s10984-005$1566-5$.

Keneley, M., and B. Jackling. 2011. "The Acquisition of Generic Skills of Culturally-Diverse Student Cohorts." Accounting Education: An International Journal 20 (6): 605-623. doi: 10.1080/09639284.2011.611344.

Kreber, C. 2003. "The Relationship between Students' Course Perception and Their Approaches to Studying in Undergraduate Science Courses: A Canadian Experience." Higher Education Research and Development 22 (1): 57-70. doi: $10.1080 / 0729436032000058623$.

Lawless, C.J., and J.T.E. Richardson. 2002. "Approaches to Studying and Perceptions of Academic Quality in Distance Education." Higher Education 44: 257-282. 
Lindblom-Ylänne, S., A. Parpala, and L. Postareff. 2018. "What Constitutes the Surface Approach to Learning in the Light of New Empirical Evidence?" Studies in Higher Education doi: 10.1080/03075079.2018.1482267.

Liu, E.S.C., C. J. Ye, and D.Y. Yeung. 2015. "Effects of approach to learning and self-perceived overall competences on academic performance of university students." Learning and Individual Differences 39: 199-204. doi: http://dx.doi.org.10.1016/j.lindif.2015.03.004.

Lizzio, A., and K. Wilson. 2004. "First-Year Students' Perceptions of Capability." Studies in Higher Education 29 (1): 109-128. doi: 10/1080.1234567032000164903.

Lizzio, A., K. Wilson, and R. Simons. 2002. "University Students' Perceptions of the Learning Environment and Academic Outcomes: Implications for Theory and Practice." Studies in Higher Education 27 (1): 27-52. doi: 10.1080/03075070120099359.

Lonka, K., P. Sharifi, K. Karlgren, I. Masinello, J. Nieminen, G. Birgegård, and A. Josephson. 2008. "Med Nord - A Tool for Measuring Medical Students' Well-Being and Study Orientations." Medical Teacher 30 (1): 72-79. doi: 10.1080/01421590701769555.

Mah, D-K., and D. Ifenthaler. 2017. "Academic Staff Perspectives on First-Year Students' Academic Competencies." Journal of Applied Research in Higher Education 9 (4): 630640.

Marton, F., and R. Säljö. 1997. "Approaches to Learning." In The experience of learning, edited by F. Marton, D.J. Hounsell, and N.J. Entwistle, 39-58. Edinburgh: Scottish Academic Press.

Monteiro, S., L. Almeida, and A. Garcia-Aracil. 2016. " Graduates' Perceptions of Competencies and Preparation for Labour Market Transition. The Effect of Gender and Work Experience during Higher Education." Higher Education, Skills and WorkedBased Learning 6(2): 208-220. 
Mora, J-G., A. García-Aracil, and L.E. Vila. 2007. "Job Satisfaction among Young European Higher Education Graduates." Higher Education 53 (1): 29-59. doi: 10.1007/s10734005-2377-4.

Nelson Laird, T. F., T. Seifert, E.T. Pascarella, M.J Mayhew, and C.F. Blaich. 2014. "Deeply Affecting First-Year Students' Thinking: Deep Approaches of Learning and Three Dimensions of Cognitive Development." The Journal of Higher Education 85 (3): $402-$ 432.

Parpala, A., and S. Lindblom-Ylänne. 2012. "Using a Research Instrument for Developing Quality at the University." Quality of Higher Education 18 (3): 313-328. doi:10.1080/13538322.2012.733493.

Parpala, A., S. Lindblom-Ylänne, E. Komulainen, T. Litmanen, and L. Hirsto, L. 2010. "Students' Approaches to Learning and Their Experiences of the Teaching-Learning Environment in Different Disciplines." British Journal of Educational Psychology 80 (2): 269-282. doi:10.1348/000709909X476946.

Paul, G., G. Hinman, S. Dottl, and J. Passon. 2009. "Academic Development: A Survey of Academic Difficulties Experiences by Medical Students and Supports Services Provided." Teaching and Learning in Medicine 21 (3): 254-260. doi: $10.1080 / 10401330903021041$

Richardson, J. T. E., and L. Price. 2003. "Approaches to Studying and Perceptions of Academic Quality in Electronically Delivered Courses." British Journal of Educational Technology 34 (1): 45-56. doi: 10.1111/1467-8535.00303.

Ruohoniemi, M., M. Forni, J. Mikkonen, and Parpala, A. 2017. "Enhancing Quality with a Research-Based Student Feedback Instrument: a Comparison of Veterinary Students' Learning Experiences in Two Culturally Different European Universities." Quality in Higher Education 23(3): 249-263. 
Räisänen, M., L. Postareff, and S. Lindblom-Ylänne. 2016. "University Students’ Self- and CoRegulation of Learning and Processes of Understanding: A Person-Oriented Approach." Learning and Individual Differences 47: 281-288.

Rytkönen, H., A. Parpala, S. Lindblom-Ylänne, V. Virtanen, and L. Postareff, L. 2012.

"Factors Affecting Bioscience Students' Academic Achievement." Instructional Science 40(2): 241-256. doi: 10.1007/s11251-011-9176-3.

Sakurai,Y., A. Parpala, K. Pyhältö, and S. Lindblom-Ylänne. 2016. "Engagement in Learning: a Comparison between Asian and European International University Students." A Journal of Comparative and International Education 46(1): 24-47.

Sharp, J. G., B. Hemmings, R. Kay, and J.C. Sharp. 2017. "Academic Boredom and the Perceived Course Experiences of Final Year Education Studies Students at University." Journal of Further and Higher Education: 1-27. doi: 10.1080/0309877X.2017.1386287.

Smith, K., S. Clegg, E. Lawrance, and M.J. Todd. 2007. "The Challenges of Reflection: Students Learning from Work Placements."Innovations in Education and Teaching International 44(2): 131-141.

Strijbos, J., N. Engels, and K. Struyven. 2015. "Criteria and Standards of Generic Competences at Bachelor Degree Level: A Review Study." Educational Research Review 14: 18-32.

Tuononen, T., A. Parpala, and S. Lindblom-Ylänne. 2017. "The transition from university to working life - An exploration of graduates perceptions of their academic competences." In Higher Education Transitions -Theory and Research, edited by E. Kyndt, V. Donche, V., K. Trigwell, and S. Lindblom-Ylänne, 238-253. Abingdon, Oxon: Routledge -Taylor \& Francis Group.

Tuononen, T., A. Parpala, M. Mattsson, and S. Lindblom-Ylänne, S. 2016. "Work Experience in Relation to Study Pace and Thesis Grade: Investigation the Mediating Role of Student Learning." Higher Education 72(1): 41-58. doi: 10.1007/s10734-015-9937-z. 
Tynjälä, P, V. Slotte, J. Nieminen, K. Lonka, and E. Olkinuora. 2006. "From University to Working Life: Graduates' Workplace Skills in Practice." In Higher Education and Working Life - Collaborations, Confrontations and Challenges, edited by P. Tynjälä, J. Välimaa, and G. Boulton-Lewis, 73-88. Amsterdam: Elsevier.

Vaatstra, R., and R. De Vries. 2007. "The Effect of the Learning Environment on Competences and Training for the Workplace According to Graduates." Higher Education 53 (3): 335357. doi: 10.1007/s10734-005-2413-4.

Van Dierendonck, D., and E. Van der Gaast. 2013. "Goal Orientation, Academic Competences and Early Career Success." Career Development International 18 (7): 694-711. doi: 10.1108/CDI-01-2013-0003.

Wilson, K., A. Lizzio, and P. Ramsden. 1997. "The Development, Validation and Application of the Course Experience Questionnaire." Studies in Higher Education 22 (1): 33-53. doi: 10.1080/03075079712331381121.

Zainuddin, Z., and C.J. Perera. 2017. "Exploring Students' Competence, Autonomy and Relatedness in the Flipped Classroom Pedagogical Model." Journal of Further and Higher Education: 1-12. Doi: 10.1080/0309877x.2017.1356916.

Zeegers, P. 2004. "Student learning in higher education: A Path Analysis of Academic Achievement in Science." Higher Education Research \& Development 23 (1): 35-56. doi: $10.1080 / 0729436032000168487$.

Zimmerman, B.J. 2002. Becoming a self-regulated learner: An Overview. Theory into Practice 41 (2): 64-70. 